\title{
Regulating backyard slaughter: Strategies and gaps in municipal livestock ordinances
}

\author{
Jennifer Blecha * \\ San Francisco State University
}

Submitted May 7, 2015 / Revised July 31 and August 23, 2015 / Accepted August 24, 2015 /

Published online December 13, 2015

Citation: Blecha, J. (2015). Regulating backyard slaughter: Strategies and gaps in municipal livestock ordinances. Journal of Agriculture, Food Systems, and Community Development, 6(1), 33-48.

http://dx.doi.org/10.5304/jafscd.2015.061.011

Copyright (C) 2015 by New Leaf Associates, Inc.

\begin{abstract}
As the alternative food movement continues to grow and urban homesteading practices spread, many cities are revising their codes to more clearly address agricultural activities. Butler's (2012) study demonstrated a set of fairly coherent strategies for regulating the keeping of poultry and livestock. Related to livestock keeping, livestock slaughter appears to be spreading as well. The regulation of backyard slaughter, however, has scarcely been addressed in the literature. Building on Butler's study, this research examines the animal policies in 22 cities and identifies five approaches to governing backyard slaughter. Many of the cities do not address the practice at all, and in others significant gaps and inconsistencies leave the regulations open to interpretation. Drawing on examples from the 22 sample cities, the final discussion considers whether and how municipalities have chosen to
\end{abstract}

* Jennifer Blecha, Department of Geography \& Environment, San Francisco State University; 1600 Holloway Avenue; San Francisco, California 94132 USA; jblecha@sfsu.edu regulate backyard slaughter, and suggests that policy-makers have a range of regulatory options for meeting local priorities, whether those are reducing nuisances, protecting public health, or addressing animal well-being.

\section{Keywords}

urban livestock, urban agriculture, nuisance, public health, slaughter, animal geographies

\section{Introduction}

During the $20^{\text {th }}$ century, the once widespread practices of backyard livestock keeping and slaughter became less common and even illegal in many U.S. cities in response to socio-economic changes and parallel shifts in municipal regulation. Of course, many cultural communities and lowincome households maintained animal practices that include backyard slaughter for economic (Arellano, 2010), cultural and familial (Pallana, 2011), or medical-religious purposes (Fadiman, 1997). However, within the dominant culture's understanding and management of the modern 
city, these individuals and communities often learned to hide, relocate, or modify their practices to fit the legal restrictions. Over the past decade a new demographic group has taken up livestock keeping in U.S. and Canadian cities: predominantly white, predominantly middle-class urban residents. Possessing greater social capital, these residents have demanded that laws be changed to allow them to keep poultry and livestock unhindered by restrictive regulations. In that period, dozens of U.S. (and to a lesser extent Canadian) cities both large and small have revisited and revised their ordinances in light of growing interest in urban livestock keeping. This trend has been the subject of recent research in legal studies and geography. Notably, William Butler (2012) examined 22 U.S. cities that had recently revised their livestock ordinances, detailing the variety of strategies and scales cities employ in managing whether and how residents may keep poultry and livestock animals. Whether or how they may kill the same animals, however, remains largely unexamined.

A decade ago, the new livestock-keepers in U.S. cities generally focused on keeping live animals for their production of eggs, milk, or honey (Blecha, 2007). Today they are increasingly choosing to slaughter animals for meat. ${ }^{1}$ As the practice of backyard slaughter becomes more widespread and visible, conflicts are arising. While some residents believe it a right to provide food for one's family and oppose any efforts to restrict animal slaughter, others find the practice abhorrent and want it banned, or at the very least kept out of residential neighborhoods (Blecha \& Davis, 2014). These conflicts indicate that cities large and small

\footnotetext{
${ }^{1}$ Choosing words to describe the killing of animals is fraught with emotion, politics, power, and meaning. Terms range from "murder," a word used regularly by anti-slaughter activists, to "processing," a term favored by practitioners, or "harvest" as suggested by one anonymous reviewer. In this paper, I use "kill" and "slaughter" in an effort to explicitly name the death of animals by human hands while avoiding the overt inflection of a particular perspective. The term "animals" itself is questionable when used in opposition to "humans," who are themselves also animals. I generally use the conventional terms "human" and "animal," though I recognize each animal's subjectivity in using personal pronouns, such as "she/her" and "who/whose."
}

across North America need to consider how to define and regulate backyard slaughter.

Using the same 22 cities, this article builds on Butler's work with a specific focus on the regulation of small-scale animal slaughter for home consumption. The following questions frame this research: (1) What regulatory strategies do these cities employ to define, permit, or restrict backyard slaughter of poultry and livestock animals? (2) Are these regulations clear, comprehensive, and coherent, and if so, what framework(s) seem to lend cohesion? (3) How do these slaughter regulations compare with those governing the keeping of live animals? This paper proceeds with a review of the relevant literature and some context for the new era of backyard slaughter. After a brief description of methodology, findings are presented. Drawing on examples from the 22 sample cities, the final discussion considers whether and how municipalities have chosen to regulate backyard slaughter, and suggests that policy-makers draw on a range of regulatory strategies for meeting local priorities, whether those are reducing nuisances, protecting public health, or addressing animal well-being. ${ }^{2}$

\section{Literature Review}

This research is situated most directly within a range of literature on the spatial history and regulation of urban livestock and animal slaughter. Other writers have outlined the process of gradual exclusion of productive animals from English, Australian, and American cities during the $19^{\text {th }}$ and $20^{\text {th }}$ centuries (Cronon, 1991; Dyl, 2006; Gaynor, 1999, 2005, 2007; Gilje, 1987; McNeur, 2011;

\footnotetext{
${ }^{2}$ Deep philosophical and political divisions exist between the positions of "animal rights" versus "animal welfare." Briefly, advocates for animal rights recognize non-human animals as sentient beings with their own interests, and seek the abolition of human use of animals for any purpose. Meanwhile, proponents of animal welfare seek to improve the quality of life and reduce the suffering of animals used by humans (Bekoff, 2009). In this paper, the term "animal well-being" is used to refer broadly to any concerns and debates that focus on the lives and experiences of animals. Specific reference to "rights" or "welfare" perspectives are used when differentiation is appropriate.
} 
Philo, 1998). A combination of factors drove this physical and emotional distancing: distaste for the nuisances of odor and noise, concern for public health due to the presence of rats and flies, new technologies that allowed for the transport of chilled milk and meat, and a desire by wealthy and business interests to remove loose animals from the streets to allow for more "dignified" mobility.

More specifically the historical geography of slaughter has also received recent attention. Scholars of urban geography and history have demonstrated how, in many cities, independent butchers (sometimes organized in a guild) were removed from city centers to their edge; this move was often accompanied by shifts in organization and increases in scale and mechanization. Commercial slaughterhouses appeared at the urban fringe, where the traditional butchers' craft was replaced by the (dis)assembly line (Atkins, 2012; Lee, 2008; Robichaud \& Steiner, 2010; Shulman, 2012). Since the 1960s, another spatial shift has transformed the slaughter industry in the U.S. Reflecting tremendous consolidation in food and agri-business generally, the meat processing industry has narrowed to a handful of corporations. Moreover, most meat consumed in the U.S. comes from animals slaughtered at a small number of large rural slaughterhouses, hidden from the sight of urban Americans. ${ }^{3}$ Geographers and other scholars have examined how these plants powerfully affect the local environment, economy, and ethnic make-up of the rural communities where they are located (Broadway \& Ward, 1990; Drabenstott, Henry, \& Mitchell, 1999; Fennelly \& Leitner, 2002; Stull \& Broadway, 2012; Stull, Broadway, \& Griffith, 1995; Ufkes, 1998; Watts, 2004).

Given this context of urban exclusion and large-scale rural slaughter, the recent return of livestock to the city is all the more remarkable. An avalanche of popular urban farming literature has

\footnotetext{
${ }^{3}$ In 2012 , four companies controlled over $70 \%$ of beef production in the U.S., operating 27 slaughterhouses. Similarly, the largest five pork producers required just 24 slaughter facilities to control $62 \%$ of the U.S. pork industry's total daily slaughter capacity. While some states have multiple USDAapproved slaughter facilities, other states have none, and their residents are indeed distant from industrial slaughter (North American Meat Institute, n.d.; Tyson Foods, 2015; U.S.
}

appeared in the past decade, signaling a renaissance for backyard chicken flocks, urban goats, rooftop beehives. A handful of scholars have begun to examine this trend, interrogating the motivations and practices of urban livestock-keepers (Blecha, 2007; Blecha \& Leitner, 2014; McClintock, Pallana, \& Wooten, 2014; Reynolds, 2010). A related body of work in geography (Blecha, 2008; Butler, 2012; LaBadie, 2008), legal studies (Orbach \& Sjoberg, 2011, 2012; Salkin, 2011a, 2011b) and public health (Tobin, Goldshear, Price, Graham, \& Leibler, 2015) has examined the regulation of urban livestock in U.S. cities, with a primary focus on the keeping of live animals (although several briefly mention slaughter). The present study is unique in its attention specifically to how U.S. cities regulate the slaughter of poultry and livestock animals at the household scale.

\section{Backyard Slaughter: A New Era}

In order to analyze municipal regulation of animal slaughter, it is important to understand why this issue is relevant in contemporary U.S. cities. ${ }^{4}$ Since 2000, a growing number of middle-class, largely white urban residents with no previous livestock experience have begun keeping small livestock or poultry in their yards in cities across the U.S. and Canada. Most commonly, they began by keeping chickens, sometimes called the "gateway animal" for urban farmers. Qualitative research with "early adopter" chicken-keepers in Seattle, Washington, and Portland, Oregon (Blecha 2007), revealed that their motivations centered on four values or goals: (1) getting high quality, organic eggs, (2) providing their chickens with a "happy, healthy" life, (3) maintaining or improving the environment, and (4) learning practical skills and teaching them to children. None of the "new urban chickenkeepers" in 2003 had any intention of slaughtering their animals (Blecha, 2007). In the past decade,

Department of Agriculture [USDA], 2015).

${ }^{4}$ Much of the contextual information in this section comes from the author's own knowledge and experiences, in addition to formal research on this topic. As a chicken-keeper for the past decade in two different cities, I have participated in classes, e-mail lists, and informal conversations with other livestock-keepers, and have read numerous urban farming books, magazines, and blogs. 
however, as the keeping of backyard chickens has become a more common hobby and the "urban homesteading" movement has gained momentum, a growing number of urban residents have slaughtered (or have at least contemplated slaughtering) an animal in their care. The discussion below explores this shift, noting that while some urban farmers intend to slaughter their animals, for others, it is simply an exit strategy from an unplanned situation.

A growing number of urban farmers are explicitly choosing to raise animals - chickens, ducks, rabbits, goats, or even pigs_-for meat. Slaughter classes are popping up in cities across the country. In Berkeley, California, the Institute of Urban Homesteading offers courses to the public such as "Home Butchering: Fowl," "Rabbit Butchering and Tanning Demonstration," and "Micro-Farming: Quail." In Oregon, the Portland Meat Collective offers classes, usually sold out, in "Basic Duck Butchery" and "Basic Pig Butchery.", Novella Carpenter, the author of an urban homesteading memoir, Farm City, has led a turkey slaughtering workshop in Austin, Texas (Carpenter, 2009) and "The Complete Rabbit" workshop in Brooklyn, New York, where participants paid US $\$ 100$ each for the opportunity to kill and clean a rabbit (Severson, 2010).

This interest in homegrown, home-slaughtered, or home-butchered meat must be understood within the larger alternative foods movement. In the 1970s and '80s, individuals with environmental or health concerns were able to shop at natural foods cooperatives in many U.S. cities. By the 1990s, they could choose from an increasing array of certified organic and hormonefree foods (Fairfax, Dyble, Guthey, Gwin, Moore, \& Sokolove, 2012). Since 2000, other signifiers (such as 'local,' 'sustainable,' 'humane, 'fair,' 'heirloom,' 'real,' 'heritage,' 'clean,' and 'GMOfree') have gained prominence even at mainstream supermarkets, making grocery shopping a complex and information-dense project for shoppers with the means and desire to "eat ethically" (Beagan, Power, \& Chapman, 2015). It is within this context

${ }^{5}$ http://www.iuhoakland.com/animals.html

${ }^{6}$ http://www.pdxmeat.com/classes/ of heightened sensitivities to all the things that can be "wrong" or "right" about our food that the food-processing skills of canning, fermenting, brewing, cheese-making, and slaughtering have gained the interest of a new generation. In a survey regarding backyard slaughter, Blecha \& Davis (2014) found that San Francisco Bay Area urban residents who supported the practice of backyard slaughter cited an array of economic, ecological, spiritual, and/or emotional reasons. They "repeatedly refer[red] to ways of raising animals that are 'humane,' 'hand-raised,' and 'humble,' while producing more healthful meat, building social connections in the community, and reducing fossil fuel use" (p. 73).

Distinct from those who intentionally raise animals for meat, many urban livestock keepers may find themselves faced with a dilemma of how to get rid of an animal they are no longer able to keep. Because roosters are banned in most U.S. cities due to their noisy crowing, most urban chicken-keepers intend to keep only hens. Thus, when buying chicks at a feed store, they generally choose chicks who have been "sexed" (that is, the females selected and the males destroyed) at the hatchery. ${ }^{7}$ Despite assurances from suppliers of at least $90 \%$ accuracy, it is not uncommon to discover a rooster or two in the flock as the chicks mature. Their keepers then need to figure out what to do with their "accidental rooster." (This situation is most common with chickens, but can also occur, for example, when a dairy goat has a male kid.)

A similar problem faces chicken-keepers with aging hens. Depending on their breed, chickens can lay 3-6 eggs per week (when not molting or on "winter break") for 2 to 3 years, with egg production declining each year. By age 5 or 6 , laying is rare. Chickens can live to age 15 or more, which means that letting chickens die of "old age" requires a willingness to feed and care for them for a decade of retirement. While the aging of hens may seem like an obvious eventuality, new chickenkeepers rarely plan for it. In an urban setting, the number of chickens one can keep is often limited by regulations or by small yards, so mature hens

\footnotetext{
${ }^{7}$ Hens lay eggs with or without a rooster.
} 
occupy space that cannot be filled with younger, egg-laying hens.

Chicken-keepers who have named their birds and raised them by hand are often fond of their birds and concerned about their fate. Even when owners decide not to keep a particular chicken any longer, they can go to considerable lengths to find new long-term homes for them. Some chickenkeepers put their roosters up for adoption at the feed store where they bought them. Many roosters are "re-homed" through advertisements in a local paper, on chicken-keeping listservs, or Craigslist ads (Blecha, 2007). Of course, not all chickenkeepers are so thoughtful. Unwanted birds are sometimes tossed over the fence into Seattle's Woodland Park Zoo during the night; presumably some are eaten by predators (Leslie, personal communication, 2003; Sven, personal communication, 2003). Chickens are sometimes simply released to "go wild"; how long they survive must vary widely. In some cases, roosters are rescued from the streets by animal welfare advocates and taken into new homes as pets. Less fortunate roosters can be captured for cockfighting, killed by dogs, or slaughtered by someone with little regard for humane treatment (Clouse, 2013).

Deciding what to do with aging hens can be a more emotionally difficult problem, as the hens have usually been named and interacted with for several years, while noisy and sometimes-aggressive roosters are often removed just a few months after arrival. In either case, faced with the options above, some chicken-keepers decide to dispatch their bird(s) themselves, hoping to do it more humanely than a stranger would. One additional circumstance of unplanned slaughter occurs when a chicken (or other small livestock) is badly injured. If a predator, a raccoon for example, gets in the coop and maims but does not kill a chicken, people must make a decision whether take the bird to a veterinarian, let it suffer, or end its misery.

Whether or not slaughter is part of owners' original plans, as livestock-keeping spreads, situations will increasingly arise in which individuals will consider killing their animals. Municipalities will need to address questions of whether and how slaughter should be done. This study examines the state of policy in advance of any concerted response from communities to this growing and potentially contentious matter.

\section{Methods}

This research builds on Butler's (2012) study of livestock-keeping regulations in 22 U.S. cities. This study uses the same sample of cities, with the goal of identifying comparable data points. For his study, Butler chose cities that had "recently revised their animal control ordinances and/or zoning ordinances to allow for urban livestock" (p. 198). Moreover, Butler designed the sample to "emphasize variability" regarding region, population size, and "approaches to managing livestock" (p. 198). Butler's sample also suits my research objective to discover how the regulation of livestock slaughter compares with the regulation of livestock keeping.

Ordinances related to urban livestock often reside in a chapter of municipal code titled "Animals" that governs licensure for pet stores, definitions of cruelty and nuisance, and what types of animals may be kept as pets. Other relevant codes are found in sections that address fishing and hunting regulations, control of pest animals or "vermin," as well as in public health, zoning, and business permits. I searched the codes of the 22 sample cities online for a series of terms, including: "slaughter," "butcher," "kill," "meat," "animal," "livestock," "poultry," "fowl," "chicken," "hen," "rooster," "duck," "rabbit," and "goat." All the relevant ordinances were captured and entered into a spreadsheet.

The data were analyzed in three phases. The first phase identified each city's slaughter rules and compared them with the livestock-keeping rules in the same cities. In Table 1, I summarize both sets of regulation data (keeping and slaughter), using Butler's framework (2012, p. 200) in order to compare them. The sample cities used a variety of schemes for categorizing animals, but here I grouped the species into a handful of categories (e.g., small, medium, and large), also following Butler. Table 1 indicates by city whether keeping and/or slaughtering of each animal type is allowed $(\checkmark)$, prohibited $(\times)$, or allowed under some circumstances $(\bullet)$. Immediately apparent in Table 1 is the large number of blank spaces in the slaughter columns, indicating that the practice is not addressed. 
Table 1. Municipal Regulations That Allow or Prohibit Keeping and/or Slaughtering Livestock by Type ${ }^{a}$

$(\mathcal{}=$ allowed; $X=$ prohibited; $\bullet=$ some in category allowed; blank $=$ none specified or unclear $)$

\begin{tabular}{|c|c|c|c|c|c|c|c|c|c|c|c|c|c|}
\hline \multirow[t]{2}{*}{ Municipality } & \multirow[t]{2}{*}{ State } & \multicolumn{2}{|c|}{ Hens } & \multicolumn{2}{|c|}{ Roosters } & \multicolumn{2}{|c|}{ Other fow $I^{b}$} & \multicolumn{2}{|c|}{ Small animals ${ }^{b}$} & \multicolumn{2}{|c|}{ Medium animals ${ }^{b}$} & \multicolumn{2}{|c|}{ Large animals $^{b}$} \\
\hline & & Keep & Slaughter & Keep & Slaughter & Keep & Slaughter & Keep & Slaughter & Keep & Slaughter & Keep & Slaughter \\
\hline Ann Arbor & MI & $\checkmark$ & $x$ & $x$ & & $x$ & & $\checkmark$ & & $x$ & & $x$ & \\
\hline Baltimore & MD & $\checkmark$ & & $x$ & & $\boldsymbol{V}^{c}$ & & $\boldsymbol{V}^{\mathrm{c}}$ & & $\boldsymbol{J}^{\mathrm{c}}$ & & $x$ & \\
\hline Bloomington & IN & $\checkmark$ & $\bullet$ & $x$ & & $\checkmark$ & & $\checkmark$ & & $\checkmark$ & & $\checkmark$ & \\
\hline Charlotte & $\mathrm{NC}$ & $\checkmark$ & $\bullet$ & $\checkmark$ & $\bullet$ & $\checkmark$ & $\bullet$ & $\checkmark$ & $\bullet$ & $\checkmark$ & $\bullet$ & $\checkmark$ & $\bullet$ \\
\hline Chattanooga & $\mathrm{TN}$ & $\bullet d$ & $\checkmark$ & $\bullet d$ & $\checkmark$ & $\bullet d$ & $\checkmark$ & $\bullet d$ & & $\bullet d$ & $\checkmark$ & $\bullet$ & \\
\hline Cleveland & $\mathrm{OH}$ & $\checkmark$ & $\bullet$ & $\checkmark$ & $\bullet$ & $\checkmark$ & $\bullet$ & $\checkmark$ & $\bullet$ & $\checkmark$ & $x$ & $\checkmark$ & $x$ \\
\hline Fort Collins & $\mathrm{CO}$ & $\checkmark$ & $x$ & $x$ & $\checkmark$ & & & & & & & & \\
\hline Kansas City & MO & $\checkmark$ & & $\checkmark$ & & $\checkmark$ & & $\checkmark$ & & $\checkmark$ & & $\checkmark$ & \\
\hline Longmont & $\mathrm{CO}$ & $\checkmark$ & $x$ & $\checkmark$ & & $\checkmark$ & & $\checkmark$ & & $\checkmark$ & & $\checkmark$ & \\
\hline Madison & WI & $\checkmark$ & $\bullet$ & $x^{e}$ & $\bullet$ & $\checkmark$ & $\bullet$ & $\checkmark$ & $\bullet$ & $\bullet$ & $\bullet$ & $\checkmark$ & $\bullet$ \\
\hline Missoula & MT & $\checkmark$ & $\checkmark$ & $\checkmark$ & & $\checkmark$ & $\checkmark$ & $\checkmark$ & $\checkmark$ & $\checkmark$ & $\checkmark$ & $\checkmark$ & $\checkmark$ \\
\hline Mobile & $\mathrm{AL}$ & $\checkmark$ & & $x$ & & $\checkmark$ & & & & $\bullet$ & & $\checkmark$ & \\
\hline Morgan Hill & $\mathrm{CA}$ & $\checkmark$ & & & & $\checkmark$ & & $\checkmark$ & & $\checkmark$ & & $\checkmark$ & \\
\hline Rogers & AR & $\checkmark$ & $\bullet$ & $x$ & & $\checkmark$ & $\bullet$ & $\checkmark$ & & $\bullet$ & & $\checkmark$ & \\
\hline Round Rock & TX & $\checkmark$ & & & & $\checkmark$ & & $\checkmark$ & & $\checkmark$ & & $\checkmark$ & \\
\hline San Antonio & TX & $\checkmark$ & & & & $\checkmark$ & & $\checkmark$ & & $\bullet$ & & $\checkmark$ & \\
\hline Santa Clara & $\mathrm{CA}$ & $\checkmark$ & $x$ & $\checkmark$ & $x$ & $\checkmark$ & $x$ & $\checkmark$ & $x$ & $\checkmark$ & $x$ & $\checkmark$ & $x$ \\
\hline Seattle & WA & $\checkmark$ & & $x$ & & $\checkmark$ & & $\checkmark$ & $\bullet$ & $\bullet$ & & $\checkmark$ & \\
\hline South Portland & ME & $\checkmark$ & $x$ & $x$ & $x$ & & & & & & & & \\
\hline Stamford & $\mathrm{CT}$ & $\checkmark$ & & $\checkmark$ & & $\checkmark$ & & $\checkmark$ & $\checkmark$ & $\checkmark$ & $\checkmark$ & $\checkmark$ & $\checkmark$ \\
\hline Tallahassee & $\mathrm{FL}$ & $\checkmark$ & $\bullet$ & $\checkmark$ & $\bullet$ & $\checkmark$ & $\bullet$ & $x$ & & $x$ & & $\bullet$ & $\bullet$ \\
\hline
\end{tabular}

a The framework of this table and the data on livestock keeping are drawn from Table 1 in Butler (2012, p. 200). Honeybees are omitted here as bees are not subject to slaughter.

b "Other fowl includes turkey, geese, ducks, etc. Small animals include rabbits. Medium animals include goats, pigs, sheep, etc. Large animals include cows, horses, alpacas, Ilamas, etc." (Butler, 2012, p. 200).

c Baltimore updated its health code in 2013 to expand the keeping of chicken hens, pigeons, rabbits, and small goats (Baltimore City Health Department, Office of Animal Control, 2013; Witt, 2013).

d Allowed only on parcels of 5 or more contiguous acres (2 or more contiguous hectares).

e Discrepancy with Butler's data, which showed that roosters are allowed. Madison code 9.52(c): "Keeping of roosters is prohibited." 
In the next phase, the cities were sorted based on similarities in how they regulate livestock slaughter versus livestock keeping. As I repeatedly read the ordinances and sorted the coded data, patterns and anomalies emerged, revealing where the slaughter ordinances are coherent, unclear, contradictory, or simply absent. While all 22 cities explicitly allow at least some livestock keeping, nearly half of them have no stated position on slaughter. In the rest of the cities, slaughter regulations vary widely. Among the sample cities I identified five different regulatory strategies, which will be outlined below. In the third phase of analysis, I coded details regarding the species and gender of animals mentioned in the ordinances and noted particular methods, locations, and purposes of slaughter that were allowed or prohibited, as well as any requirements for individual slaughterers.

\section{Findings}

Through repeated reading and coding of the ordinance data, I identified five "approaches" to livestock regulation among the sample cities, which I call silent, quiet, probibiting, uneven, and conditional (Table 2).

The cities categorized as silent are those whose codes make no mention of slaughter at all. In some of these cases, such as Ann Arbor, Michigan, and Baltimore, Maryland, most of the silences are in reference to animals already prohibited from the city. However, even types of animals that are allowed in cities are commonly unaddressed. For example, five cities (Kansas City, Missouri; Longmont, Colorado; Missoula, Montana; Mountain View, California; and Stamford, Connecticut) allow roosters to be kept within the city but are silent on the issue of rooster slaughter. The slaughter of other types of permissible animals was left out even more frequently (hens, 9 cities; other fowl, 10; small animals, 9; medium animals, 6; large animals, 11). It is unclear whether these gaps are intentional or simply oversight.

Closely related to silence is an approach I call quiet. In these cases, no ordinance directly addresses slaughter, but other laws acknowledge the practice and give tacit approval. Four of the cities in this study are quiet on slaughter. For example, while the city code of Mobile, Alabama, does not mention the act of slaughter per se, animals "slaughtered for food within 24 hours" are exempt from dead animal reporting laws (Section 7-20(b)). In Mountain View, stores are prohibited from selling young chicks or rabbits whose down or fur has been artificially colored; however, they are allowed to sell the same naturally colored animals "to be raised for food purposes only." This phrase addresses only the raising of animals, not their demise, but there is no other way that rabbits become "food" than by killing them. Contradictions and loopholes may be vestiges of old laws still on the books or existing in whole other chapters of the municipal code. Whatever the case, despite the absence of explicit permission for slaughter, these cities quietly imply consent.

A third group of cities have uneven regulations by species or sex. For example, Ann Arbor, allows both hens and rabbits to be kept. However, while the law explicitly prohibits the slaughter of chickens (hens or roosters), it does not mention rabbits, creating a loophole for those who would like to raise rabbits for meat. Similarly, Longmont specifically prohibits the slaughter of hens, but not roosters. Here is a case where "accidental roosters" may not be kept, but may be killed.

The problems of this uneven approach would seemingly be solved in cities of the fourth group, which simply probibit all slaughter. For example, in Santa Clara, California, "it is unlawful for any person, by any means, to slaughter any animal within the city...('Slaughter' means to kill an animal for food or butcher.)" These cities allow the keeping of hens, but with a prohibition on slaughter the law carries an implicit expectation that hens will be kept until the natural end of their lives. In a city with a strict slaughter prohibition, the killing of senior hens could conceivably be pushed "underground." Another challenge that may arise from a blanket prohibition is if a commercial slaughter operation or recreational fishing is unintentionally banned.

The fifth approach to regulation is conditionalthat is, slaughter is allowed under particular conditions. Out of 132 regulatory opportunities (22 cities $\times 6$ types of animals), municipalities prescribe in detail where, how, or why slaughter is 


\begin{tabular}{|c|c|c|c|}
\hline Municipality & State & Regulations on keeping poultry and livestock & Regulations on backyard slaughter \\
\hline \multicolumn{4}{|c|}{ Silent on slaughter } \\
\hline Baltimore & MD & Chickens, rabbits, and small goats allowed. & Silent on slaughter. \\
\hline Chattanooga & $\mathrm{TN}$ & Swine, goats, and fowl allowed on large ( $\geq 5$ acres or 2 ha) lots only. & Silent on slaughter. \\
\hline Round Rock & TX & Fowl allowed. Medium and large animals on big lots only. & Silent on slaughter. \\
\hline San Antonio & TX & Fowl, medium, and large animals allowed. & Silent on slaughter. \\
\hline Kansas City & MO & Chickens and rabbits allowed. Limited roosters. & Silent on slaughter. \\
\hline \multicolumn{4}{|c|}{ "Quiet" on slaughter (permission implied) } \\
\hline Mobile & $\mathrm{AL}$ & Hens allowed. No roosters. Cows with permit. Silent on rabbits. & $\begin{array}{l}\text { Animals "slaughtered for food within } 24 \text { hours" are exempt from dead } \\
\text { animal reporting laws. }\end{array}$ \\
\hline Stamford & CT & Poultry and livestock allowed. & Residents may use firearms on own property to kill livestock. \\
\hline Mountain View & $\mathrm{CA}$ & $\begin{array}{l}\text { Poultry and rabbits allowed. Permit needed for medium and large } \\
\text { animals. No roosters except agricultural zones. }\end{array}$ & $\begin{array}{l}\text { Stores may display and sell young poultry and rabbits "to be raised fo } \\
\text { food purposes only." }\end{array}$ \\
\hline \multicolumn{4}{|c|}{ Slaughter prohibited by species or sex } \\
\hline Ann Arbor & $\mathrm{Ml}$ & Hens and rabbits allowed. & Slaughter of chickens prohibited. Silent on rabbits. \\
\hline South Portland & ME & $\begin{array}{l}\text { Hens allowed. Quiet on other animals except they must not run } \\
\text { loose in parks or highways. }\end{array}$ & Slaughter of chickens prohibited. Otherwise silent. \\
\hline \multicolumn{4}{|c|}{ Slaughter prohibited } \\
\hline Santa Clara & $\mathrm{CA}$ & Fowl, rabbits, and other small, medium, and large animals allowed. & Slaughter prohibited. \\
\hline Fort Collins & $\mathrm{CO}$ & Hens allowed; no roosters. & Slaughter prohibited. \\
\hline \multicolumn{4}{|c|}{ Slaughter conditional (depending on circumstances) } \\
\hline Bloomington & IN & Chickens allowed. & Slaughter prohibited on harborer's property. \\
\hline Charlotte & $\mathrm{NC}$ & Fowl, small, medium, and large animals allowed with permit. & $\begin{array}{l}\text { Slaughter allowed if humane, sanitary, hidden, and not otherwise } \\
\text { prohibited. }\end{array}$ \\
\hline Cleveland & $\mathrm{OH}$ & $\begin{array}{l}\text { Poultry, small, and medium animals allowed with permit. Medium } \\
\text { animals on big lots only. }\end{array}$ & $\begin{array}{l}\text { Slaughter of chickens, ducks, rabbits, and similar small animals } \\
\text { allowed on site and for consumption by occupants only. }\end{array}$ \\
\hline Madison & WI & Hens and other fowl allowed. & $\begin{array}{l}\text { Slaughter of chickens prohibited on site. Permit needed to slaughter } \\
\text { medium and large livestock. }\end{array}$ \\
\hline Missoula & MT & Hens and rabbits allowed. & $\begin{array}{l}\text { Prohibited to kill animals except "commonly accepted agricultural ano } \\
\text { livestock practices." (Unclear if and how slaughter is included.) }\end{array}$ \\
\hline Rogers & AR & Hens allowed. No roosters and no hogs. Silent on other animals. & Slaughter of chickens prohibited "outside." \\
\hline Tallahassee & $\mathrm{FL}$ & Hens and limited roosters allowed. & Prohibited to “inhumanely kill...any animal." \\
\hline
\end{tabular}


allowed in 24 of them. Seven cities mention particular stipulations for slaughter, regarding location, conditions, and/or purpose (Table 3). These details provide initial insights into the local policy priorities (such as nuisance prevention, public health, or animal well-being) behind these policies, which are discussed below.

\section{Discussion}

As the practice of livestock keeping spreads and backyard slaughter likely follows, municipalities across the U.S. will increasingly face the question of whether and how to limit or shape these practices. In Butler's (2012) analysis, cities used regulations at different spatial scales to restrict where and how livestock animals could be kept. At the municipal scale, certain species were simply prohibited citywide, thereby indicating that these animals were incompatible with the municipality's vision of itself as an urban space. In the present study, at least five of the 22 cities explicitly prohibited slaughter of one or more animal species, taking a clear stance that slaughter is out of place within their municipality.

While Butler found that most cities chose to provide detailed codes for livestock keeping, the present study demonstrates that city codes offer few specifics regarding slaughter. For example, in three cities with uneven regulations, the code prohibited slaughter of one species or sex but it failed to address other animals allowed in the city. Several quiet cities mention slaughter in a roundabout manner while discussing other issues, but do not address the issue head on. Even those cities that explicitly allow for slaughter under some circumstances, those circumstances are poorly defined, particularly in regard to location. Cities differed in where they require slaughter to take place. In Cleveland, Ohio, residents may slaughter poultry and small animals "on site," while in Madison, Wisconsin, residents are prohibited from slaughtering “on site." In Bloomington, Indiana, residents "shall not slaughter chickens on harborer's property." As written, the laws appear to allow residents to slaughter their chickens, as long as they do not do it at home. The intent of the codes is unclear: did Madison and Bloomington intend to prohibit slaughter, or actually hold that it would be better for the "harborer" to kill their chickens at a neighbor's house instead? In none of these slaughter ordinances are there detailed specifications similar to those commonly prescribed for livestock keeping.

Butler argues that well-crafted regulationswhether detailed or flexible — can help municipalities navigate potential challenges associated with the return of urban livestock. Butler identifies two core conflicts that policy-makers needs to manage: tensions around animals and practices seen as "rural" in an urban setting, and concerns about public health. These two issues are also associated, of course, with slaughter, and the present research indicates that the relevant regulations are less than robust. The discussion below explores how cities might address and/or prevent conflicts over appropriate urban land use, safeguard public health, and-in response to a third tension-balance animal well-being with (human) desires for food and liberty. This discussion concludes by considering reasons why municipalities may or may not want to provide more detailed slaughter regulations.

One function of more detailed slaughter ordinances could be to define and prevent nuisances. Butler describes these types of detailed guidelines as part of a zoning tradition that aims to "minim[ize] negative impacts on the users of neighboring properties" (Butler, pp. 208-209). Some cities in this study have specific ordinances that could help accomplish this. Charlotte, North Carolina, specifies that slaughter "shall not be done open to the view of any public area or adjacent property owned by another" (Charlotte Code Part II, Sec 3-102(c4)). Similarly, Rogers, Arkansas, prohibits slaughter "outside." These restrictions would limit the visual (and probably aural) impact on neighbors. Other guidelines could include a permitted period for slaughter similar to hunting and fishing seasons or a limit on the number or type of animals slaughtered per year. These types of regulations - of type, number, and site-are common in ordinances governing urban livestock keeping, and could be useful if cities want to minimize nuisance conflicts between neighbors.

Protecting public health is another reason to regulate backyard slaughter. Several serious 
Table 3. Slaughter Regulations Dependent on Variables of Location, Conditions, and Purpose

\begin{tabular}{|c|c|c|c|c|c|c|c|c|c|c|c|c|c|}
\hline \multirow[b]{2}{*}{ Municipality } & \multirow[b]{2}{*}{ State } & \multicolumn{6}{|c|}{ Regulations by type of animal } & \multirow{2}{*}{$\begin{array}{l}\text { Location } \\
\text { On site }^{a}\end{array}$} & \multicolumn{4}{|c|}{ Conditions } & \multirow{2}{*}{$\begin{array}{l}\text { Purpose } \\
\text { Food }^{f}\end{array}$} \\
\hline & & Hens & Roosters & Other fowl & $\begin{array}{c}\text { Small } \\
\text { animals }\end{array}$ & $\begin{array}{l}\text { Medium } \\
\text { animals }\end{array}$ & $\begin{array}{c}\text { Large } \\
\text { animals }\end{array}$ & & $\begin{array}{l}\text { Hidden from } \\
\text { view }^{b}\end{array}$ & Humane $^{c}$ & Sanitaryd & Permite & \\
\hline Bloomington & IN & a & & & & & & Prohibited & & & & & \\
\hline Charlotte & $\mathrm{NC}$ & $\mathrm{bcd}$ & bcd & $b c d$ & $b c d$ & $b c d$ & $b c d$ & & Human & Required & Required & & \\
\hline Cleveland & $\mathrm{OH}$ & ae & ae & ae & ae & & & Required & & & & & Required \\
\hline Madison & WI & $a$ & $a$ & $f$ & $f$ & $f$ & $f$ & Prohibited & & & & Required & \\
\hline Rogers & AR & b & & b & & & & & $\begin{array}{l}\text { Prohibited } \\
\text { outside }\end{array}$ & & & & \\
\hline Seattle & WA & & & & $b d$ & & & & Animal & & Required & & \\
\hline Tallahassee & $\mathrm{FL}$ & c & c & & & & & & & Required & & & \\
\hline
\end{tabular}

a Slaughter performed "on site" or "on harborer's property"-required or prohibited.

o Slaughter must be hidden from view of the public and/or neighbors ("human”) or from others of its species (“animal”), or is prohibited outside.

: Slaughter must be "humane."

"Slaughter must be "sanitary."

ə For consumption by household only.

f Permit required.

infectious diseases, including avian influenza, E. coli, and salmonella can be transmitted through livestock, and poultry in particular. ${ }^{8}$ In light of this risk cities have a range of regulatory options ranging from education to prohibition. In a recent study of infectious disease outbreaks in the U.S. that can be traced to backyard poultry, Tobin et al. (2015) generated a set of seven recommendations for urban poultry ordinances in order to reduce this risk. These include prescriptions for frequent hand-washing, proper composting of wastes, and special attention to children, who are "more likely to touch, kiss, or snuggle live poultry (particularly chicks), put their hands in their mouth, and inconsistently practice hand washing" (p. 388). Of the seven recommendations, only one was rigid: "3. Prohibit slaughter at

${ }^{8}$ The relative risk posed to public health by backyard versus commercial poultry flocks is important to bear in mind. In an outbreak of highly infectious avian influenza in 2003, Bavinck, Bouma, Van Boven, Bos, Stassen, and Stegeman (2009) found that "backyard flocks were considerably less susceptible to infection than the home" (p. 389). The authors argue,

slaughtering animals on site in urban environments poses opportunities for pathogen transmission from infectious birds to the environment, humans, and other animals. The urban household environment is not well suited for containment of pathogens from the slaughtering of birds, including viscera, blood, and feces, and in particular may draw wild and domesticated animals to the premises. (p. 389)

While not contradicting these potential disease vectors, this author questions the necessity of prohibiting slaughter on these

commercial farms" (p. 247). Furthermore, Smith and Dunipace (2011) found that "the contribution of backyard poultry flocks to the on-going transmission dynamics of an avian influenza epidemic in commercial flocks is modest at best" (p. 71). 
grounds. Tobin et al. provide data on 22 outbreaks of salmonella in the U.S. since 1990; in every case, the source was contact with live poultry, not participation in slaughter. Although their article repeatedly warns that animal slaughter "poses a risk for pathogen transmission" (p. 389), the authors provide no examples of disease being spread that way, which begs the question whether slaughter is actually more dangerous for public health than keeping live birds. If good hygiene practices protect practitioners as they handle live birds and clean out coops, it seems possible that similar practices could protect them during slaughter. If one of the key concerns is contamination of children, surely it is easier to keep young children away from an occasional slaughter event than from the daily presence of live animals. Moreover, children would be less drawn to "touch, kiss, or snuggle" a dead chicken than a fluffy baby chick.

Tobin et al. argue persuasively that municipalities should require education on hygiene and disease prevention in order to grant a poultrykeeping permit. Rather than ban slaughter outright, municipalities could require similar instruction in sanitary slaughter and disposal of offal. For example, the state of Minnesota has worked with several live animal markets ${ }^{9}$ to establish clear health guidelines for their customers. The Minnesota departments of agriculture and public health have produced posters and fliers in English, Spanish, Hmong, Somali, and Amharic that instruct customers in "healthy market" practices, such as washing their hands before and after shopping, transporting their purchases in a chilled and insulated container, and cooking the meat thoroughly (Minnesota Department of Health, 2015). These kinds of instructions could be provided to those who wish to slaughter at home as well. In this study, both Seattle and Charlotte require slaughter to be done in a "sanitary" manner, but what that means is not defined or described for the benefit of the practitioner.

Another type of regulation with a bearing on public health is restricting the sale or distribution of home-processed meats. One city in this study,

${ }^{9}$ At live markets, customers choose from an assortment of live fowl, goats, pigs, or other animals, who are then slaughtered
Cleveland, specifies that "chickens, ducks, rabbits and similar small animals may be slaughtered on site only if for consumption by the occupants of the premises" (emphasis added). This intent of this law is unstated, but a likely goal is limiting the health impacts of improper slaughter. A more explicit example of this kind of restriction is the 2004 Minnesota law restricting the types of homegrown and home-processed food that can be sold in the state. Known as the "Pickle Bill," it allows the sales of pickles, fruits, and vegetables (with a $\mathrm{pH} \leq 4.6$ ) but prohibits the sale of all home-processed meat (Minnesota Department of Agriculture, n.d.). Alternatively, in 2011 the town of Sedgwick, Maine, passed a "food sovereignty" law which gave residents " "the right to produce, process, sell, purchase, and consume local foods of their choosing" (Michaelis, 2011, para. 2), including locally produced meat and raw milk. These examples begin to show the options for regulation, including restricting the consumption of homegrown meat to the immediate household.

A third tension that can arise over the issue of slaughter is an ethical disagreement over the treatment of animals. In a survey of 345 urban San Francisco Bay Area residents, Blecha and Davis (2014) found drastically different perspectives on the practice of backyard slaughter. Some respondents who were opposed to the practice expressed concerns about nuisance or disease like those discussed above. Another group, however, described deep horror and moral outrage at the thought of animals being killed anywhere, but especially by their neighbors. They considered the killing of living beings murder and eating their bodies repugnant. Among those who supported the practice, two additional views emerged. Some respondents interested in "alternative" or "local" foods felt that animals raised by hand in a backyard setting generally had a far happier life and less painful and frightening death than those raised in the mainstream corporate food system. Others in the survey expressed reservations about the notion of backyard slaughter, but defended the "right" of residents both to feed themselves and to do what they

on site, usually by market staff. At some facilities customers have the option to clean and butcher the animal themselves. 
want on their own property as long as it does not affect their neighbors. Blecha and Davis (2014) found that for many participants in the survey, these perspectives reflect deeply held values that participants wanted to see reflected in their city's ordinances.

We were surprised by the strength of feeling subjects conveyed. Even though the survey was lengthy and responding to the openended questions was optional, a majority of participants provided answer to all ten, often at length. The vigor of participation indicates that some portion of the public feels strongly, even passionately, about this issue... (p. 71)

Given these sorts of passions among the public, municipalities can face serious conflicts over the issue of slaughter.

Every municipality is different, of course, and residents' feelings about slaughter will vary with the local history and mix of cultures. In some towns with a relatively homogenous population, it may be fairly easy to outline local ethical norms regarding slaughter. In cities with a more diverse population the discussion can be fraught. Animal rights activists have vigorously opposed backyard slaughter in several communities, and recently succeeded in getting a slaughter ban passed in Minneapolis, Minnesota (City Council of City of Minneapolis, 2012). In Oakland, California, vociferous disagreement between slaughter and anti-slaughter activistswith up to 300 attending a single hearing — delayed the approval of an updated urban agriculture ordinance for several years. Eventually the new policy was approved after it excluded any decision on livestock keeping and slaughter (Zigas, 2011, 2014). Finally, municipalities must be careful about restricting practices that are important to the cultural traditions or ritual practices of minority communities. Filipino, Mexican, and Hmong communities, among others, have some animal practices that differ from Euro-American norms (Griffith, Wolch, \& Lassiter, 2002; Park, Quinn, Florez, Jacobson, Neckerman, \& Rundle, 2011; Xiong, Numrich, Wu, Yang, \& Plotnikoff, 2005). Municipalities attempting to draft slaughter regulations would do well to consult with and consider the perspectives of diverse residents.

Of the cities in this study, only Charlotte and Tallahassee, Florida, specify that slaughter be accomplished in a "humane" manner, although that term remains undefined. In Seattle, slaughter of any small animal must take place out of sight of other animals of its kind. The rationale for this provision is not mentioned in the ordinance, but presumably it is to prevent fear or distress among the other animals. Along with hygiene training, cities could also require education about humane methods of slaughter.

\section{Recommendations and Conclusions}

Whatever a municipality's motivation for or approach to managing this growing practice, policy-makers would do well to consider thoughtfully how they will address the issue of slaughter in their community. In his study of the livestockkeeping laws of these 22 cities, Butler found two different regulatory styles, each with a key strength and weakness. Most of the cities provided detailed guidelines, especially regarding poultry: "the keeping of fowl in residential areas is highly regulated with setbacks, number limits, permitting processes, and detailed management specifications" (Butler, 2012, p. 209). With this detailed approach, "clarity and predictability is high, but where specifications are overly stringent, some individuals will be unable to engage in the practice of livestock keeping where they live" (p. 210). A looser management style was taken by a smaller number of cities, where "the codes specify the enforcement official and use vague language to describe what constitutes a nuisance or health violation" (p. 210). This approach allows for more creativity by urban farmers and discretion by administrators to suit local conditions; however, "such flexibility also could lead to inconsistent application of the intent of the law which could be construed as unfair or capricious" (p. 210). Butler argues that either strategy has the potential to effectively meet a municipality's goals of safeguarding public health and minimizing nuisances.

Additionally, a third option exists. Municipalities may choose to leave their position on the practice undefined to prevent the escalation of a 
conflict where one had not previously existed. For example, when El Cerrito, California, was in the process of revising its animal codes, the city council was reluctant to wade into the issue of slaughter. One council member expressed concern that regulating slaughter could become politically and legally challenging if it interfered with any residents' religious or cultural traditions (Burress, 2012). Avoiding taking a stand on the issue may also have neutralized some of the passionate debates about animal rights versus residents' rights to feed themselves that arose at public hearings in nearby Oakland. Along the same lines, the city attorney advised the council that,

Using the nuisance abatement approach would be the most effective means of dealing with animal slaughter, at least until there is some evidence that the practice is being used widely in the City to the detriment of the public health, safety, and welfare. (Woodruff, 2012)

The city council of El Cerrito chose not to stir up a potentially controversial debate in the city when many of the possible ills brought by slaughter could be controlled by nuisance laws already in place. Policy-makers in cities where slaughter has not been addressed will want to weigh the potential value of a public debate on this issue. If regulation is desired, they might also consider whether looser or more detailed ordinances would better serve their community.

As this is the first study of this topic, the discussions and conclusions in this paper are an entrée into an area of both theoretical interest and practical value. A study using a larger sample of cities would allow for a better understanding of the range and types of slaughter regulations currently on the books. In addition, case studies might trace the processes, constituencies, and rationale(s) behind the regulatory choices of individual cities. As practices of urban agriculture continue to expand in the U.S., more municipalities will find themselves facing issues related to small-scale livestock slaughter. This research offers some preliminary context for policy-makers when considering whether and how to address the practice.

\section{Acknowledgements}

I would like to thank Xiaohang Liu, Kerri Meyer, and Marion Blecha for their help and encouragement as I prepared this manuscript. Additionally, the critiques provided by a JAFSCD anonymous reviewer resulted in key improvements.

\section{References}

Arellano, G. (2010, September 16). Mexicans were the original frugalistas [Radio show commentary]. In S. Nieves (Senior producer), Marketplace. St. Paul, Minnesota: American Public Media. Retrieved from http://www.marketplace.org/topics/world/ mexicans-were-original-frugalistas

Atkins, P. (Ed.). (2012). Animal cities: Beastly urban histories. Surrey, England: Ashgate.

Baltimore City Health Department, Office of Animal Control. (2013). Regulations for wild, exotic and bybrid animals. Retrieved from http://communitylaw.org/ wp-content/uploads/2013/09/AC-Reg-WildExotic-Hybrid-Animals-September-26-2013.pdf

Bavinck, V., Bouma, A., Van Boven, M., Bos, M. E. H., Stassen, E., \& Stegeman, J. A. (2009). The role of backyard poultry flocks in the epidemic of highly pathogenic avian influenza virus (H7N7) in the Netherlands in 2003. Preventive Veterinary Medicine, 88(4), 247-254. http://dx.doi.org/10.1016/ j.prevetmed.2008.10.007

Beagan, B. L., Power, E. M., \& Chapman, G. E. (2015). "Eating isn't just swallowing food": Food practices in the context of social class trajectory. Canadian Food Studies/La Revue canadienne des études sur l'alimentation, 2(1), 75-98. http://dx.doi.org/10.15353/cfs-rcea.v2i1.50

Bekoff, M. (Ed.). (2009). Encyclopedia of animal rights and animal welfare (Second ed.). Santa Barbara, California: ABC-CLIO.

Blecha, J. L. (2007). Urban life with livestock: Performing alternative imaginaries through small-scale urban livestock agriculture in the United States (Doctoral dissertation). Retrieved from ProQuest, Publication No. 3273113.

Blecha, J. L. (2008, October). Regulating urban livestock: Comparing municipal animal ordinances in 104 US and Canadian cities. Paper presented at the Community Food Security Coalition Annual Conference, Philadelphia, Pennsylvania. 
Blecha, J. L., \& Davis, A. (2014). Distance, proximity, and freedom: Identifying conflicting priorities regarding urban backyard livestock slaughter. Geoforum, 57, 67-77. http://dx.doi.org/10.1016/i.geoforum.2014.08.010

Blecha, J. L., \& Leitner, H. (2014). Reimagining the food system, the economy, and urban life: New urban chicken-keepers in U.S. cities. Urban Geography, 35(1), 86-108. http://dx.doi.org/10.1080/02723638.2013.845999

Broadway, M. J., \& Ward, T. (1990). Recent changes in the structure and location of the US meatpacking industry. Geography, 75(1), 76-79. http://www.jstor.org/stable/40571938

Burress, C. (2012, February 6). El Cerrito takes up backyard animal slaughter. El Cerrito Patch. Retrieved from http://patch.com/california/ elcerrito/el-cerrito-takes-up-backyard-animalslaughter

Butler, W. H. (2012). Welcoming animals back to the city: Navigating the tensions of urban livestock through municipal ordinances. Journal of Agriculture, Food Systems, and Community Development, 2(2), 193-215.

http://dx.doi.org/10.5304/jafscd.2012.022.003

Carpenter, N. (2009, October 15). Turkey class: Austin, Texas [Blog post]. Retrieved from http://ghosttownfarm.wordpress.com/2009/10/15 turkey-class-austin-texas/

City Council of City of Minneapolis. (2012). An ordinance of the city of Minneapolis: Amending Title 20, Chapter 520 of the Minneapolis Code of Ordinances relating to zoning code: Introductory provisions. Retrieved from http://www.minneapolismn.gov/www/groups/ public/@citycoordinator/documents/webcontent/ wcms1p-090596.pdf

Clouse, B. (2013). Increased demands on chicken run rescue for placement of "urban farm" animals. Chicken Run Rescue. Retrieved from http://www.brittonclouse. com/chickenrunrescue/surrender chart4 13.pdf

Cronon, W. (1992). Nature's metropolis: Chicago and the great West. New York: W. W. Norton.

Drabenstott, M., Henry, M., \& Mitchell, K. (1999). Where have all the packing plants gone? The new meat geography in rural America. Bureau of Business Research Publications, Paper 13.

Dyl, J. L. (2006). The war on rats versus the right to keep chickens: Plague and the paving of San
Francisco, 1907-1908. In A. C. Isenberg (Ed.), The nature of cities (pp. 38-61). Rochester, New York: University of Rochester Press.

Fadiman, A. (1997). The spirit catches you and you fall down: A Hmong child, her American doctors, and the collision of two cultures. New York: Farrar, Straus and Giroux.

Fairfax, S., Dyble, L. N., Guthey, G. T., Gwin, L., Moore, M., \& Sokolove, J. (2012). California cuisine and just food. Cambridge, Massachusetts: MIT Press.

Fennelly, K., \& Leitner, H. (2002). How the food processing industry is diversifying rural Minnesota (Working Paper No. 59). East Lansing, Michigan: Julian Samora Research Institute, Michigan State University.

Gaynor, A. (1999). Regulation, resistance and the residential area: The keeping of productive animals in twentieth-century Perth, Western Australia. Urban Policy and Research, 17(1), 7-16. http://dx.doi.org/10.1080/08111149908727786

Gaynor, A. (2005). Harvest of the suburbs: An environmental bistory of growing food in Australian cities. Perth, Western Australia: University of Western Australia Publishing.

Gaynor, A. (2007). Animal agendas: Conflict over productive animals in twentieth-century Australian cities. Society \& Animals, 15(1), 29-42. http://dx.doi.org/10.1163/156853007X169324

Gilje, P. A. (1987). The road to mobocracy: Popular disorder in New York City, 1763-1834. Chapel Hill: University of North Carolina Press.

Griffith, M., Wolch, J., \& Lassiter, U. (2002). Animal practices and the racialization of Filipinas in Los Angeles. Society \& Animals, 10(3), 221-248. http://dx.doi.org/10.1163/156853002320770056

LaBadie, K. T. (2008). Residential urban chicken keeping: An examination of 25 cities [Undergraduate research paper]. University of New Mexico, Albuquerque, New Mexico. Retrieved from http://66.147.242. 185/ urbanch5/wp-content/uploads/2012/02/ Ordinance-research-paper.pdf

Lee, P. Y. (Ed.). (2008). Meat, modernity, and the rise of the slaughterhouse. Durham: University of New Hampshire Press.

McClintock, N., Pallana, E., \& Wooten, H. (2014). Urban livestock ownership, managment, and regulation in the United States: An exploratory survey and research agenda. Land Use Policy, 38, 426-440. http://dx.doi.org/10.1016/j.landusepol. $\underline{2013.12 .006}$ 
McNeur, C. (2011). The "swinish multitude": Controversies over hogs in antebellum New York City. Journal of Urban History, 37(5), 639-660. http://dx.doi.org/10.1177/0096144211407561

Michaelis, K. (2011). State of Maine challenges food sovereignty [Blog post]. Retrieved from http://www.foodrenegade.com/state-of-mainechallenges-food-sovereignty/

Minnesota Department of Agriculture. (n.d.). Pickle Bill fact sheet. Retrieved July 29, 2015, from http://www.mda.state.mn.us/food/safety/minnfood-code-fact-sheets/pickle-bill.aspx

Minnesota Department of Health. (2015). Healthy markets. Retrieved from http://www.health. state.mn.us/divs/idepc/dtopics/animal/market/ index.html

North American Meat Institute. (n.d.). Top 10 beef and pork slaughterers and estimated daily slaughter capacity, November 2010. Retrieved April 12, 2015, from https://www.meatinstitute.org/index.php? $\underline{\mathrm{ht}=\mathrm{a} / \text { GetDocumentAction/i/67186 }}$

Orbach, B. Y., \& Sjoberg, F. R. (2011). Excessive speech, civility norms, and the clucking theorem. Connecticut Law Review, 44(1), 1-59. http://connecticutlawreview.org/

Orbach, B., \& Sjoberg, F. R. (2012). Debating over backyard chickens (Arizona Legal Studies Discussion Paper No. 11-02). CONNtemplations, 44(1), 1-32. http://dx.doi.org/10.2139/ssrn.1742930

Pallana, E. (2011). Chicken dinner does not equal gang violence [Blog post]. Pluck and Feather Blog.

Park, Y., Quinn, J., Florez, K., Jacobson, J., Neckerman, K., \& Rundle, A. (2011). Hispanic immigrant women's perspective on healthy foods and the New York City retail food environment: A mixed-method study. Social Science \& Medicine, 73(1), 13-21. http://dx.doi.org/10.1016/ j.socscimed.2011.04.012

Philo, C. (1998). Animals, geography, and the city: Notes on inclusions and exclusions. In J. Wolch \& J. Emel (Eds.), Animal geographies: Place, politics, and identity in the nature-culture borderlands (pp. 51-71). London: Verso. http://dx.doi.org/10.1068/d130655

Reynolds, K. A. (2010). Urban agriculture as revolution: An action research and social movement analysis of food production in Alameda County, California (Doctoral dissertation). University of California, Davis, California.

Robichaud, A., \& Steiner, E. (2010). Trail of blood: The movement of San Francisco's Butchertown and the spatial transformation of meat production, 1849-1901 (Working Paper). Stanford, California: Stanford University Spatial History Lab. Retrieved from http://www.stanford.edu/group/spatialhistory/ cgi-bin/site/pub.php?id=31

Salkin, P. (2011a). Feeding the locavores, one chicken at a time: Regulating backyard chickens. Zoning and Planning Law Report, 34(3), 1-12.

Salkin, P. (2011b). Honey, it's all the buzz: Regulating neighborhood beehives. Boston College Environmental Affairs Law Review, 39, 55-71. http://ealr.bclawreview.org/

Severson, K. (2010, March 2). Don't tell the kids. The New York Times. Retrieved from http://www.nytimes.com/2010/03/03/dining/ 03rabbit.html

Shulman, R. (2012). Eat the city: A tale of the fishers, foragers, butchers, farmers, poultry minders, sugar refiners, cane cutters, beekeepers, winemakers, and brewers who built New York. New York: Broadway Books.

Smith, G., \& Dunipace, S. (2011). How backyard poultry flocks influence the effort required to curtail avian influenza epidemics in commercial poultry flocks. Epidemics, 3(2), 71-75. http://dx.doi.org/10.1016/j.epidem.2011.01.003

Stull, D. D., \& Broadway, M. J. (2012). Slaughterhouse blues: The meat and poultry industry in North America. Belmont, California: Wadsworth, Cengage Learning.

Stull, D. D., Broadway, M. J., \& Griffith, D. (1995). Any way you cut it: Meat processing and small-town America. Lawrence, Kansas: University Press of Kansas.

Tobin, M. R., Goldshear, J. L., Price, L. B., Graham, J. P., \& Leibler, J. H. (2015). A framework to reduce infectious disease risk from urban poultry in the United States. Public Health Reports, 130(4), 380-391. http://www.publichealthreports.org

Tyson Foods. (2015). Production facility locations. Retrieved April 12, 2015, from http://www.tysonfoods careers.com/Production/Facility-Locations.aspx

Ufkes, F. M. (1998). Building a better pig: Fat profits in lean meat. In J. Wolch \& J. Emel (Eds.), Animal geographies: Place, politics and identity in the nature-culture borderlands (pp. 241-255). London: Verso. 
U.S. Department of Agriculture [USDA]. (2015). FSIS

meat, poultry and egg product inspection directory.

Retrieved from http://www.fsis.usda.gov/wps/ wcm/connect/a5c2b5c8-92e0-4565-8999-

f2fb75bfdb05/MPI Directory Establishment Number.pdf?MOD=AJPERES

Watts, M. (2004). Are hogs like chickens? Enclosure and mechanization in two 'white meat' filières. In A. Hughes \& S. Reimer (Eds.), Geographies of commdity chains (pp. 39-62). London: Routledge.

Witt, B. (2013, September 27). New adopted animal regulations for Baltimore City! [Blog post]. Retrieved from the Community Law Center website: http://communitylaw.org/ urbanagriculturelawproject/final2013regs

Woodruff, S., \& Pinkos, K. (2012). Agenda bill: Agenda Item No. 4(B) and Attachment 1. El Cerrito, California. Retrieved from http://www.elcerrito.org/DocumentCenter/Home/View/1204
Xiong, P., Numrich, C., Wu, C. Y., Yang, D., \& Plotnikoff, G. A. (2005). Hmong shamanism: Animist spiritual healing in America's urban heartland. In L. L. Barnes \& S. S. Sered (Eds.), Religion and healing in America (pp. 439-454). Oxford, UK: Oxford University Press.

Zigas, E. (2011). Feathers fly over backyard farming rules in Oakland [Blog post]. SPUR. Retrieved from http://www.spur.org/blog/2011-07-26/feathersfly-over-backyard-farming-rules-oakland

Zigas, E. (2014). Oakland clears the path for new urban agriculture [Blog post]. SPUR. Retrieved from http://www.spur.org/blog/2014-12-07/oaklandclears-path-new-urban-agriculture 